\title{
Dynamics of ionic species in Svalbard annual snow: the effects of rain event and melting
}

Elena Barbaro ${ }^{1}$, Cristiano Varin ${ }^{2}$, Xanthi Pedeli ${ }^{2,3}$, Jean Marc Christille ${ }^{4,5}$, Torben Kirchgeorg2, Fabio Giardi ${ }^{6}$, David Cappelletti ${ }^{7}$, Clara Turetta $^{1}$, Andrea Gambaro ${ }^{2}$, Andrea Bernagozzi ${ }^{4}$, Jean 5 Charles Gallet $^{8}$, Mats P. Björkman ${ }^{9}$, Andrea Spolaor ${ }^{*}$.

${ }^{1}$ Institute for the Dynamics of Environmental Processes, IDPA-CNR, Via Torino 155, 30172 Venice-Mestre, Italy

${ }^{2} \mathrm{Ca}$ ' Foscari University of Venice, Department of Environmental Sciences, Informatics and Statistics, Via Torino 155, 30172 Venice-Mestre, Italy.

$10{ }^{3}$ Athens University of Economics and Business, Department of Statistics, 76 Patision Street, 10434 Athens, Greece.

${ }^{4}$ Astronomical Observatory of the Autonomous Region of the Aosta Valley (OAVdA), Loc. Lignan 39, 11020 Nus (AO), Italy.

${ }^{5}$ Dipartimento di Fisica e Geologia, Università degli Studi di Perugia, I-06123 Perugia, Italy

$15{ }^{6}$ Chemistry Department - Analytical Chemistry, Scientific Pole, University of Florence, Via della Lastruccia 3, I-50019 Sesto Fiorentino (Florence) Italy.

${ }^{7}$ Dipartimento di Chimica, Biologia e Biotecnologie, Università degli Studi di Perugia I-06123 Perugia, Italy

${ }^{8}$ Norwegian Polar Institute, Tromsø, NO-9296, Norway

$20{ }^{9}$ University of Gothenburg, Department of Earth Sciences, Box 460, 40530 Göteborg, Sweden

*Correspondence to: Andrea Spolaor IDPA-CNR, (andrea.spolaor@enr.it)

Keywords: ions, Svalbard, snow, melting effect. 
25 Abstract. The Arctic and middle latitude (such as the Alps) ice core archives, except for the Greenland summit, are strongly influenced by melting processes, able to modify the original chemical signal of the annual snowfall. In the last decades, the increase of the average Arctic temperature has caused and enhanced surface snow melting in the higher ice cap, especially in the Svalbard Archipelago. The increase of the frequency and altitude of winter "rain on snow" events as

30 well as the increase of the length of the melting season has a direct impact on the chemical composition of the seasonal and permanent snow layers due to different migration processes of water-soluble compounds, such as ionic species. The re-allocation along the snowpack of ionic species could significantly modify the original chemical signal present in the annual snow, making comprehensive interpretation of climate records difficult. The chemical composition of the first 100 $\mathrm{cm}$ of the seasonal snow at Austre Brøggerbreen Glacier (Spitsbergen, Svalbard Islands, Norway) was monitored daily from the $27^{\text {th }}$ of March until to the $31^{\text {st }}$ of May 2015. The experiment period covers almost the entire Arctic spring until the melting season. During the experiment, a rain event occurred on the $16^{\text {th }}$ to $17^{\text {th }}$ of April while from the $15^{\text {th }}$ of May the snowpack reached an isothermal profile. The presented dataset is unique and helps to better understand the behaviour of cations $\left(\mathrm{K}^{+}\right.$,

$\left.40 \mathrm{Ca}^{2+}, \mathrm{Na}^{+}, \mathrm{Mg}^{2+}\right)$, anions $\left(\mathrm{Br}^{-}, \mathrm{I}^{-}, \mathrm{SO}_{4}{ }^{2-}, \mathrm{NO}_{3}{ }^{-}, \mathrm{Cl}^{-}, \mathrm{MSA}\right)$ and two carboxylic acids $\left(\mathrm{C}_{2}\right.$-glycolic and $\mathrm{C}_{5}$-glutaric acids) in the snowpack during this melting period. The results obtained from the experiment give us an overview of how the chemicals are remobilized in the snowpack during a rain event or due to the melting at the end of the spring season. The aim of this paper is to give a picture of the evolution of the seasonal snow strata with the aim to better understand the processes that can

45 influence the chemical distribution in the annual snow. The results of the present work are unique and helpful for future analyses and interpretation of ice core paleoclimatic archives. 


\section{Introduction}

50 After the first study conducted by Dansgard et al. (1969), ice cores are intensively studied for a better understanding of the climate dynamics (EPICA Community members, 2004). A long list of elements, isotopes and chemical compounds are currently analysed to reconstruct the past climate conditions (Wolff et al., 2010). For examples, calcium, aluminium, iron, and magnesium are studied to quantify the changes in the atmospheric dust load in the past (Wolff et al., 2010). Potassium could be influenced by multiple sources like sea spray aerosol, dust deposition and biomass burning (Legrand and Mayewski, 1997). Sodium and chloride are used as sea salt tracers to quantify the influences of the marine aerosol (Schüpbach et al., 2018), while stable water isotope ratio reflects atmospheric temperature changes (Stenni et al., 2011). Sulphate and in particular well-defined peaks of non-sea salt sulphate are commonly used to identify volcanic events, supporting the ice core dating (Sigl et al., 2014). Methanesulphonic acid (MSA) can reflect the past marine primary production and, in a specific case, changes in sea ice conditions (Curran et al., 2003; Isaksson et al., 2005). Parallel to well consolidate climate tracers, other elements and compounds are recently emerging. Bromine and iodine have been suggested to respond to sea ice changes and biological primary production (Cuevas et al., 2018; Spolaor et al., 2016a; Spolaor et al., 2014) and free amino acids are currently under examination, as possible tracers of marine primary production (Barbaro et al., 2017a).

The seasonal snow layer can be defined as the snow accumulated above the equilibrium line during one year on glaciers while the snow cover that melts during the summer above ground and defined as the snow accumulated and present on the ground during the year. The seasonal snow layer is an extremely dynamic portion of the cryosphere (Valt and Salvatori, 2016). The snow deposited and accumulated over the glaciers reflects the average atmospheric composition relative to the time of its deposition and its post-depositional processes and preserves information about the transport processes of atmospheric aerosol (Barbante et al., 2004; Spolaor et al., 2014). In the polar region, in particular in the higher and colder ice caps, the annual snow strata can be preserved and the snow accumulation from year to year then provides proxies for climate reconstructions.

Snow metamorphism is defined as the change of macrophysical snow properties, such as density, grain size, and shape, and it is a function of the temperature gradient within the snowpack (Colbeck, 1982) which is strongly depended on the atmospheric conditions. Several processes can influence the annual signal in the accumulated snow; snow can be removed or restructured by wind; postdepositional processes can modify the abundance of particular photo-reactive elements; water formation and percolation into the snow pack can redistribute the soluble chemical species present into the snow pack (Brimblecombe et al., 1987). One of the main issues regarding the interpretation 
of the chemical signal in ice and snow is the effect of the surface melting and subsequent water percolation, modifying the pristine chemical signal of the annual snow pack and altering the climate information (Pohjola et al., 2002; Vega et al., 2016). Only few studies (Björkman et al., 2014; Eichler et al., 2001; Goto-Azuma et al., 1994; Kuhn, 2001; Pohjola et al., 2002; Vega et al., 2016) have tried to estimate this ion reallocation effects on the annual chemical signals in ice cores, an important issue for ice-climate proxies from regions where summer snow melting occurs, and where will occur more in the next future due to the Arctic temperature rising (Kohler et al., 2007). It is

90 likely that an increasing number of Arctic ice fields and caps, including the Greenland Plateau (Nilsson et al., 2015) will experience summer melting in the near future reducing drastically the location where pristine ice signal could be collected $\backslash$ present.

The results of Pohjola et al. (2002) and Vega et al. (2016) focus on the final effect of the summer melting, describing and characterizing the behaviour of the ionic species into the snowpack $\backslash$ firn.

95 Their results showed an increase of the mobility for ionic species linked with strong acid $\left(\mathrm{SO}_{4}{ }^{2-}\right.$ and $\mathrm{NO}_{3}{ }^{-}$). There is still lack of knowledge regarding the fundamental behaviour of ions in the snow pack during the melting phase and, even more important, during specific and rapid meteorological events such as the "rain on snow" events.

The aim of the present research has been to investigate the pristine distribution and the subsequent mobility of soluble species in the snow by monitoring the daily changes of the first meter of the annual snowpack from the early spring (cold climate) until the late spring when the melting phase is on-going. The upper $100 \mathrm{~cm}$ of the annual snowpack of the Austre Brøggerbreen glacier (Spitsbergen, Svalbard Archipelago) has been sampled on a daily basis with a resolution of $10 \mathrm{~cm}$ from $27^{\text {th }}$ March to $31^{\text {st }}$ May 2015. Each snow sample was analysed for anions $\left(\mathrm{Br}^{-}, \mathrm{I}^{-}, \mathrm{NO}_{3}{ }^{-}, \mathrm{SO}_{4}{ }^{2-}\right.$,

$\left.105 \mathrm{Cl}^{-}\right)$, cations $\left(\mathrm{K}^{+}, \mathrm{Na}^{+}, \mathrm{Mg}^{2+}, \mathrm{Ca}^{2+}\right)$, MSA, and two carboxylic acids $\left(\mathrm{C}_{2}\right.$-glicolic and $\mathrm{C}_{5}$-glutaric acids). The main physical parameters, such as temperature and liquid water content, have been acquired with a continuous measuring system. Temperature sensors $(n=11)$ were positioned with 10 $\mathrm{cm}$ depth resolution, while $25 \mathrm{~cm}$ depth resolution has been used for the liquid water sensors $(\mathrm{n}=3)$. Snow layer identification and hardness test were also performed. This is the first time that such 110 daily sampling has been done in Polar regions and which include a strong melt event, which is unique to study the mobility of the soluble compounds in a changing seasonal Arctic snowpack. 


\section{Experimental design}

\section{The Sampling site}

The experiment was conducted on the Austre Brøggerbreen (ABB) glacier $\left(78.88916^{\circ} \mathrm{N}\right.$, $\left.11.89008^{\circ} \mathrm{E}\right)$ in the vicinity of the research facilities in Ny-Ålesund, Svalbard Archipelago. The average annual precipitation in Svalbard ranges from 190 to $525 \mathrm{~mm}$. The Ny-Ålesund area has an annual precipitation of $385 \mathrm{~mm}$ and its highest precipitation rates occur in August-October (mainly rain) and March (mainly snow), while May-June correspond to the lowest rates (Førland et al., 2011). Mean annual temperature is $-6.3^{\circ} \mathrm{C}$, and February is usually the coldest month $(-14.6 \pm 3.4$ ${ }^{\circ} \mathrm{C}$ ) while July is the warmest period $\left(4.9 \pm 0.8^{\circ} \mathrm{C}\right.$ ) (Maturilli et al., 2013). ABB is a small glacier, characterized by a seasonal snow cover that melts during summer (hence, no accumulation region) and has an average snow depth of $2.5 \mathrm{~m}$ at the upper part of the glacier. The ABB elevation increase is constant, with the bottom is located at $45 \mathrm{~m}$ a.s.1. and the top is located at $490 \mathrm{~m}$ a.s.1., with a length of approximately $7 \mathrm{~km}$ and it is confined in a valley by the surrounding mountains. The annual snow pack at the bottom part of the ABB is strongly characterized by melt and refrozen layer while the upper section usually is well preserved with only a few thin melt and refrozen strata $(<0.5 \mathrm{~cm})$.

\section{Sampling strategy}

The snowpack sampling was conducted at the middle of the ABB between the $27^{\text {th }}$ March and $31^{\text {st }}$ May 2015. An area of $10 \times 10 \mathrm{~m}$ was chosen on the glacier at an elevation of $270 \mathrm{~m}$ a.s.1. on a flat area. This area is usually well protected from wind erosion and surface snow redistribution, minimizing post-depositional relocation. Eight plastic poles were used to delimit the designed area as well as to calculate the accumulation $\backslash$ ablation of the surface snow. Accumulation is needed as a background parameter to identify the evolution of the annual snow pack and correct the snow pit depth for the following sampling. Additionally to the accumulation data, meteorological time series is crucial to understand if the increase in snow depth is due to precipitations or a depletionlerosion a consequence of snowdrift and/or melting. Accumulation data were obtained by daily measurements

140 of the height of the eight plastic poles compared to the snow surface. A mean value of these measurements was calculated to obtain the average daily loss or gain of snow. The average daily standard deviation of the accumulation measured form the six poles was $3.5 \mathrm{~cm}$.

A one-meter deep snow pit was daily dug perpendicular to the glacier elongation using a clean aluminium shovel. Before sampling the snow, surface was scratch with a dedicated clean

145 polyethylene shovel. The snow wall was sampled using polyethylene pre-cleaned tubes with a depth increment of $10 \mathrm{~cm}$ so that 10 samples were taken each time. After sampling, the snow pit was 
(1) 
.

.

Due to the lower concentration of $\mathrm{Br}$ and $\mathrm{I}$, the measurements were conducted by Inductively 180 Coupled Plasma Collision reaction cell mass Spectrometry (CRC-ICP-MSS; Agilent 7500 series) equipped with a Scott-cooled spray chamber (ESI, Omaha, USA). This analytical system provides no information about the chemical species but quantifies the total amount of the selected element. Detection limits, calculated as three times the standard deviation of the blank, were $50 \mathrm{pg} \mathrm{g}^{-1}$ for

${ }^{79} \mathrm{Br}$ and $10 \mathrm{pg} \mathrm{g}^{-1}$ for ${ }^{127} \mathrm{I}$. The analytical system was cleaned during 3 min with $2 \% \mathrm{HNO}_{3}$ (trace metal grade, Romil, UK), then 3 min with ultrapure water, and that in cycles during $24 \mathrm{~h}$ prior each analyses session. At the beginning of each analysis, a single cleaning cycle was run to return the background to within $1 \%$ of the initial background level to minimize possible residual memory effect

\section{Meteorological data}

190 The meteorological data have been obtained by the AWIPEV (https://www.awipev.eu/awipevobservatories) weather station at their research base located in Ny-Ålesund (5 km from the experimental site) since there are no operating weather stations present on the sampling site. For the discussion of our results, we considered only the air temperature (PT100 sensor in ${ }^{\circ} \mathrm{C}$ ) (Maturilli et al., 2013). Other meteorological parameters obtained at Ny-Ålesund have not been included in the

195 discussion because likely influenced by the orography around the ABB glacier. The snow accumulation has been estimated by measuring the length of six plastic poles placed around the sampling location while the daily precipitation data were recorded in Ny-Ålesund by the Norwegian Meteorological Institute (station n. 99910) and downloaded through the eKlima database (eklima.no). The precipitation data was only included characterizing the precipitation amount

200 during the rain events since the main important aspect for the experiment is the snow accumulated $\backslash$ removed to $\backslash$ from the sampling site.

\section{Temperature and liquid water content}

A continuous system for temperature and LWC, expressed as a percentage of the mass of snow in a liquid phase, has been installed in the snow at the sampling site. 11 temperature probes were buried 205 in the snow at $10-\mathrm{cm}$ intervals from the surface down to a depth of $1 \mathrm{~m}$ while 3 soil moisture sensors were buried at 25, 50 and $75 \mathrm{~cm}$ depth (depth refers to the first days and corrections have been applied using the accumulation data). The setup for the thermal and liquid water content revelation system consists essentially of three parts. The main box contains the electronic acquisition system, based on Arduino's open-source standard, with a DLS2.0 shield for the logging

210 part. The second box contains the board for connecting all probes involved in the experiment: 11 temperature probes plus 3 soil moisture sensors. The temperature probes were Maxim Dallas 
DS18B20. Their resolution was set to 12 Bits, yielding a readout of up to $750 \mathrm{~ms}$. Pull-up resistors of 4.7 Kohm eliminate all parasite signals. The Liquid water content are derived from soil moisture sensors (SparkFun Soil Moisture Sensor SEN-13322) where the resistance increases as the medium becomes drier and reaches zero when totally covered by water. The temperature probe was checked by means of one-hour continuous measurements at $+25^{\circ} \mathrm{C}$ and $-15^{\circ} \mathrm{C}$ controller environment and in parallel with a standard thermometer. The soil moisture sensor for measuring the liquid water content (LWC \% per mass) were calibrated by carrying out a measurement in air-dry conditions ( $0 \%$ saturation) and by immersing them in melted snow collected from the sampling site (100\%). The raw signal value ranged between 0 in absence of liquid water to 680 when fully immersed in melted snow of the sampling site. A more detailed description of the station set up can be found in Spolaor et al. (2016b).

\section{Snowpack characterization}

225 The Svalbard snow pack is very variable in term of properties and structure, due to the influence of the ocean and the constant shift between cold, warm, calm and windy conditions. A marked alteration of the internal snow layers structure can occur during rain events, while the snow surface properties will mostly be influenced by solid precipitation and atmospheric conditions (wind, air and radiation). The different snow layers can be distinguished by the density, type, and shape of 230 snow crystals and the resistance to the penetration (hardness). The properties of a snow layer have a direct effect on the redistribution of ionic species into the snow pack if melting occurs, as it influences the permeability of the snow. During the entire experiment, hardness and stratigraphy were evaluated within 5-days resolution. The resolution was increased in case of specific meteorological events to better understand the evolution of the snow pack layering in concomitance with strong perturbation.

\section{Statistical analysis}

The experiment was characterized by two major events, namely the rain on the $16^{\text {th }}$ of April and the start of the melting phase defined on the $15^{\text {th }}$ of May. The beginning of the melting period was more difficult to estimate accurately, since some melt-refreezing cycles certainly occurred before the $15^{\text {th }}$ of May. Anyway by that time the melting occurred in the entire snowpack, the temperature profile was isothermal and close to the melting point. In these conditions we expect water to be able to percolate from the top down the bottom of the snowpack in one single event without refreezing in the middle of the snow column. 
(1)

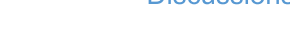

245 We carried out a statistical analysis to identify which ions were the most significantly affected by each event. All the data were aggregated according to the concentrations levels found in the snow column: three levels corresponding to depths 10-20, 30-50 and $60-90 \mathrm{~cm}$ for the biogenic compounds (MSA, $\mathrm{NO}_{3}^{-}, \mathrm{C} 2$ and C5) and four levels corresponding to depths 10-40, 50, 60-90 and $100 \mathrm{~cm}$ for the other ions. The concentrations were averaged over the depth levels and then transformed on the logarithm scale to remove the skewness in the distribution of the averaged concentrations.

To investigate if the two events of $16^{\text {th }}$ April and $15^{\text {th }}$ May had a notable effect on the observed series of each ion, we evaluated the presence of statistically significant local level shifts corresponding to the events. More specifically, we considered observations in a neighborhood of 255 the event and test if the mean level changed after the event. The neighborhood consisted of one week before and one week after the event. In order to reduce the effect of isolated outliers, the statistical test of a level shift was built upon a linear regression model fitted with a robust $\mathrm{M}$ estimator (Huber, 1981), as implemented in the function rlm of the R package (R Core Team, 2018) MASS (Venables and Ripley, 2002). The effect of each event was considered highly significant if 260 the corresponding p-value is below 0.001, significant if the p-value lies between 0.001 and 0.01 and weakly significant if the p-value lies between 0.01 and 0.05 .

\section{Results}

\section{Meteorological conditions, snow temperature and liquid water content}

During our experiment, three different synoptic events have been observed, which resulted in three 265 different temperature gradient regimes in the snow. Therefore, the experiment can be divided into three phases. Phase 1 (March 27 - April 16, P1 in the following) was first characterized by a cold and stable air temperature until a rain event occurred on $17^{\text {th }}$ of April. During P1, the temperature gradient in the snowpack was weak (below $10{ }^{\circ} \mathrm{C} \mathrm{m}^{-1}$ ) with no melting occurring. Phase 2 (April 17- May 15, P2) was first characterized by the rain event that produced an almost uniform thermal 270 gradient in the snow, but still with negative temperature values $\left(-3\right.$ to $\left.-5{ }^{\circ} \mathrm{C}\right)$. A decrease of air temperature followed and cold propagated in the deeper snow layers. Finally, on 15th of May, after a period of warming, the snow temperature profile became almost isotherm but snow surface started to melt, which defines the third period (May 15-30, P3). Air and snow temperature profile together with snow LWC can be seen on Fig.2.

275 The dry period, P1, the rain event, P2, and the melting period, P3, defined above are in agreement with the LWC data. No liquid water was detected in the P1, while during P2, the LWC increased to $38 \%$ over the entire system, which is likely to be overestimated. We hypothesise that the device 
created a small confined area where water could be preferentially stored, or that the device got flooded, which explains the very high value recorded, but also the data gap 16 to $18^{\text {th }}$ of April as the electronic system has been damaged by the water. Even after fixing the system, the LWC at $50 \mathrm{~cm}$ depth was still as high as 6 to $8 \%$ even if the snow temperature decreased down to $-10{ }^{\circ} \mathrm{C}$, which is physically unrealistic. We, therefore, do not use the LWC data after that event at $50 \mathrm{~cm}$ depth. No liquid water has been detected at $75 \mathrm{~cm}$ depth, even during the rain event. During the melting phase, the LWC increased though the entire snow column and finally reached the bottom part of our measured profile at $75 \mathrm{~cm}$ on the $26^{\text {th }}$ of May. The constant increase of LWC is also consistent with the propagation of the heat wave through the snowpack.

\section{Snow structure and layering}

A simplified snow stratigraphy with only the hardness of the snow layers was recorded every 5 days through the experiment (Figure S1). During P1, most of the snow was soft and surface changed occurred due to fresh snow events, wind, compaction of the recent snow and the deeper layers due to snow metamorphosis, which increased the hardness of the top $20 \mathrm{~cm}$ of the snow pack. The middle part of the snowpack was medium-hard with some layer up to a hardness index of 4 . The bottom of the investigated snow was characterized by a very thick and hard layer, which is typical for Svalbard glacier and consists of the early snow accumulated during late autumn or early winter.

295 The P2, after the rain event, shows a substantial increase in the hardness of the snowpack as the snow got saturated with water and refrozen (Fig S1). The hardness of the top $20 \mathrm{~cm}$ increased with several new ice and melt-refrozen layers and between 20 and 50-60 cm. After the $15^{\text {th }}$ of May, during the melting phase, the hard layers are re-allocated to the bottom of the snowpack. A lot of variability in the appearing and disappearance of the very hard layers is also observed, which is

300 typical for a melting snow pack subjected to refreezing period at night time. A large part of the snow pack became very hard between 40 and $80 \mathrm{~cm}$ depth so that a lot of the percolated material got refrozen in these layers. Fresh snow has also been deposited at the surface during that phase.

\section{Major ions distribution in the snow pack}

The average composition of first 1-m snow was mainly characterized by marine input and the ions 305 related to the sea spray aerosol were the most abundant species, i.e. $\mathrm{Na}^{+}, \mathrm{Cl}^{-}$and $\mathrm{SO}_{4}{ }^{2-}$. The average concentrations ranged between 2 and $8 \mu \mathrm{g} \mathrm{g}^{-1}$ for $\mathrm{Na}^{+}(45 \%$ of the total sum of all detected ionic species), 1.1 and $3.5 \mu \mathrm{g} \mathrm{g}^{-1}$ for $\mathrm{Cl}^{-}(25 \%)$, and 0.8 and $3.2 \mu \mathrm{g} \mathrm{g}^{-1}$ for $\mathrm{SO}_{4}{ }^{2-}(19 \%)$ during the entire experiment (Fig. S2). Magnesium and nitrate represented $4 \%$ and $3 \%$ of the total sum of all detected ionic species, with concentrations ranged between 0.1 and $0.8 \mu \mathrm{g} \mathrm{g}^{-1}$ and 0.08 and $0.5 \mu \mathrm{g} \mathrm{g}^{-1}$, 
respectively. Calcium and potassium were found at the same mean percentage $(2 \%)$ with concentration values between 81 and $580 \mathrm{ng} \mathrm{g}^{-1}$ for $\mathrm{Ca}^{2+}$ and 88 and $313 \mathrm{ng} \mathrm{g}^{-1}$ for $\mathrm{K}^{+}$. The other ions were found with a percentage below of $1 \%$, as reported in Fig. S2.

For the following discussion, the chemical dataset has been divided into two sub-groups considering both the literature (Legrand and Mayewski, 1997). MSA, $\mathrm{NO}_{3}^{-}, \mathrm{C} 2$ and $\mathrm{C} 5$ are species mostly influenced by biogenic activities, such as algal bloom and oceanic primary production (Björkman et al., 2014b; Chebbi and Carlier, 1996; Isaksson et al., 2005). The other species $\left(\mathrm{Na}^{+}\right.$, $\mathrm{Cl}^{-}, \mathrm{Ca}^{2+}, \mathrm{Mg}^{2+}, \mathrm{K}^{+}, \mathrm{Br}$ ) are connected with physical processes such as sea spray aerosol formation and dust transport (long range and local) (Röthlisberger et al., 2002). Sulphate and the total iodine may originate from both sources: sea spray emission and biogenic activities (e.g. algae bloom) (Maffezzoli et al., 2017; Minikin et al., 1998).

Fig. 2 and 4 report the concentrations of ionic species found in the daily $1-\mathrm{m}$ snow pit with a resolution of $10 \mathrm{~cm}$ for the entire experiment (from $27^{\text {th }}$ of March to $31^{\text {st }}$ of May). Considering the profiles reported in Fig. 2 and 4, three different concentration levels can be distinguished for biogenic ions (MSA, $\mathrm{NO}_{3}^{-}, \mathrm{C} 2$ and $\mathrm{C} 5$ ) at $10-20 \mathrm{~cm}, 30-50 \mathrm{~cm}$ and $60-100 \mathrm{~cm}$ while four concentration levels can be identified for other ions at 10-40 cm, $50 \mathrm{~cm}, 60-90 \mathrm{~cm}$ and $100 \mathrm{~cm}$. The median concentrations of each ion, divided for each strata and each period, are reported in Tables S1 and S2.

The compounds related with the biogenic emission, in particular MSA, $\mathrm{NO}_{3}{ }^{-}$, and $\mathrm{C} 5$ showed rather homogeneous concentrations until the end of April and the snow layers had low concentrations of these species without a specific stratification. However slightly higher concentration is detected in the upper stratum. The MSA demonstrated an homogenous concentration in the lower stratum (60$100 \mathrm{~cm}$ ) with median concentrations ranged between 1 and $2 \mathrm{ng} \mathrm{g}^{-1}$ in the three different periods. The superficial layer $(10-20 \mathrm{~cm})$ was the most affected stratum and MSA concentrations varied from $16 \mathrm{ng} \mathrm{g}^{-1}$ to $34 \mathrm{ng} \mathrm{g}^{-1}$ in the P1 and P2, respectively, and $136 \mathrm{ng} \mathrm{g}^{-1}$ in the P3. The middle 335 stratum of MSA was quite stable with median concentrations of $5 \mathrm{ng} \mathrm{g}^{-1}, 14 \mathrm{ng} \mathrm{g}^{-1}$ and $22 \mathrm{ng} \mathrm{g}^{-1}$ for each consecutive phase, respectively. Similar behaviour was demonstrated for C5, its concentration increased further as a function of time, slowly affecting the deeper layers but never reached the last one (Fig. 2 and Table S1). An increase of the concentration in P3 was also measured for nitrate and $\mathrm{C} 2$ but affected almost the entire snow pack, as shown in Fig. 2.

340 Other compounds $\left(\mathrm{Br}^{-}, \mathrm{K}^{+}, \mathrm{Mg}^{2+}, \mathrm{Ca}^{2+}, \mathrm{Cl}^{-}\right.$and $\left.\mathrm{Na}^{+}\right)$showed a similar distribution during $\mathrm{P} 1$ with higher concentration detected in the layers below $50 \mathrm{~cm}$ depth and in particular between 50 and 60 $\mathrm{cm}$ depth. During the P1, the chemical distribution in the 1-m snow pack remained stable without 


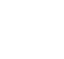

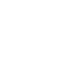

,

, 
(2)

elution sequence depends strongly from the stratigraphy of the snowpack and it is very important evaluate each single stratum.

The behaviour of iodine is particularly interesting. Iodine is a chemical species that is reactive under light condition. From a millennial scale, iodine is controlled by atmospheric concentration derived by biological emission (Cuevas et al., 2018). However, this experiment can difficultly assess the role of the primary production since is likely that iodine deposited in the upper snow can be later released back into the atmosphere. The rain event and the snow melting, that cause the presence of liquid water into the snow pack, had a great impact in the iodine distribution in the snow pack (Fig.

485 2). In particular, the highest concentration of iodine in the snow pack (Table S2) has been detected in the P1 of the experiment. This evidence might be due to the lower incoming solar radiation compare to the later periods, then the rain event produced a significant negative level shift at the 50 cm stratum (Frieß et al., 2010; Spolaor et al., 2014). The melting event produced a negative level shift at the $50 \mathrm{~cm}$ and $60-90 \mathrm{~cm}$ strata, while the upper stratum $(10-40 \mathrm{~cm})$ did not show any

490 statistically relevant level shift probably due to a continuous input for the atmospheric deposition, such as other biogenic markers.

\section{Conclusions}

A daily sampling of the first meter of snowpack was carried out in the Austre Brøggerbreen glacier (Spitsbergen, Svalbard Islands) from $27^{\text {th }}$ March to $31^{\text {st }}$ May 2015. The main aim of this experiment was to describe the daily physical and chemical changes of a snowpack occurred during a rain event and during the initial period of melting phase is on-going. This is the first field experiment about the evolution of chemical composition of snowpack in a Svalbard glacier. Understanding the dynamics of ions during these specific events is mandatory to use these species as climatic proxies in ice cores archives. A statistical approach was applied to identify the effects of the rain event and the melting

500 phase on the ion re-allocation into the snowpack. This comprehension is becoming important considering the frequency increase of these phenomena in recent years due to changing climate conditions.

The present study describes the drastic change in the chemical structure of the 1-m snowpack produced by rain event because the percolation of liquid water had the capability to wash out the

505 ions and re-allocate them within the snowpack. Saline components $\left(\mathrm{Na}^{+}, \mathrm{Cl}^{-}, \mathrm{SO}_{4}{ }^{2-}, \mathrm{Ca}^{2+}, \mathrm{Mg}^{2+}, \mathrm{K}^{+}\right.$, $\mathrm{I}^{-}$) were mainly affected by the rain events because biogenic species (MSA, C2, C5 and $\mathrm{NO}_{3}^{-}$) showed lower concentrations in the period when the event occurred. The most influenced stratum was the $50 \mathrm{~cm}$, due to the percolation of liquid water in vertical water channel where the ionic species were washed out in the deeper levels (below of $100 \mathrm{~cm}$ ). At the contrast, the melting phase 
510 produced a general decrease of all ionic species, starting from the superficial layers, except for the biogenic compounds (MSA, C2 and C5) which showed a positive level shift due to continuous atmospheric deposition. Then, the effect of melting propagated in the lower strata until the hardest strata (ice lens, or melt/refrozen layers) which acted as physical barriers to preserve the allocation of ions.

515 The present study proposes an unique dataset of ionic composition in the 1-m seasonal snow layer at daily temporal resolution and $10 \mathrm{~cm}$ depth resolution. The results obtained suggest significant different dynamics of the ionic compounds during the rain event and during the initial phase of melting. Though ion elution sequences have already been proposed, we demonstrate within this experiment that the elution sequence is not a standardize process and it can change in connection with different meteorological events, snow physical properties, as well as the liquid water content, complicating the interpretation and the drawing up of an uniform elution sequence. The presented dataset constitutes the first snapshot of the snow pack evolution from chemical and physical point of view based on real data. This study, first of its kind, seeks to improve our comprehension on processes connect with the presence of liquid water in the snow pack, a condition that will become more frequent in the warming Arctic also in the higher and isolated ice cap.

\section{Acknowledgments}

We would like to thank all our colleagues at the CNR Dirigibile Italia Arctic Station who worked and helped us during the field campaign. The logistical support of the National Research Council Department of Earth System Science and Environmental Technologies (CNR-DTA) is gratefully 530 acknowledged. Special thanks are also due to the Norwegian colleagues and the Norwegian Polar Institute for supporting and joining the field operations. Financial support was also received from the Swedish Foundation of Olle Engkvist Byggmästare to M.P. Björkman. The authors thank Elga Lab water, High Wycombe UK for supplying the pure water systems used in this study. 
Bales, R. C., Davis, R. E. and Stanley, D. A.: Ion Elution Through Shallow Homogeneous Snow, Water Resour. Res., 25(8), 1869-1877, doi:10.1029/WR025i008p01869, 1989.

Barbante, C., Schwikowski, M., Döring, T., Gäggeler, H. W., Schotterer, U., Tobler, L., Van De Velde, K., Ferrari, C., Cozzi, G., Turetta, A., Rosman, K., Bolshov, M., Capodaglio, G., Cescon, P. 540 and Boutron, C.: Historical record of European emissions of heavy metals to the atmosphere since the 1650s from alpine snow/ice cores drilled near Monte Rosa, Environ. Sci. Technol., 38(15), 4085-4090, doi:10.1021/es049759r, 2004.

Barbaro, E., Spolaor, A., Karroca, O., Park, K. T., Martma, T., Isaksson, E., Kohler, J., Gallet, J. C., Bjorkman, M. P., Cappelletti, D., Spreen, G., Zangrando, R., Barbante, C. and Gambaro, A.: Free

545 amino acids in the Arctic snow and ice core samples: Potential markers for paleoclimatic studies, Sci. Total Environ., 607-608, 454-462, doi:10.1016/j.scitotenv.2017.07.041, 2017a.

Barbaro, E., Padoan, S., Kirchgeorg, T., Zangrando, R., Toscano, G., Barbante, C. and Gambaro, A.: Particle size distribution of inorganic and organic ions in coastal and inland Antarctic aerosol, Environ. Sci. Pollut. Res., 24(3), 2724-2733, doi:10.1007/s11356-016-8042-x, 2017b.

550 Björkman, M. P., Kühnel, R., Hodson, A., Sattler, B. and Psenner, R.: Microbial Cell Retention in a Melting High Arctic, Arctic, Antarct. Alp. Res., 46(2), 471-482, doi:10.1657/1938-4246-46.2.471, 2014a.

Björkman, M. P., Vega, C. P., Kühnel, R., Spataro, F., Ianniello, A. and Roberts, T. J.: Nitrate postdeposition processes in Svalbard surface snow, J. Geophys. Res. Atmos., 119(3), 12953-12976, 555 doi:10.1002/ 2013JD021234, 2014b.

Brimblecombe, P., Clegg, S. L., Davies, T. D., Shooter, D. and Tranter, M.: Observations of the preferential loss of major ions from melting snow and laboratory ice, Water Res., 21(10), 12791286, doi:10.1016/0043-1354(87)90181-3, 1987.

Chebbi, A. and Carlier, P.: Carboxylic acids in the troposphere, occurence, sources, and sinks: a 560 review, Atmos. Environ., 30(24), 4233-4249, doi:10.1016/1352-2310(96)00102-1, 1996.

Colbeck, S. C.: An Overview of Seasonal Snow Metamorphism, Rev. Geophys., 20(1), 45-61, doi:10.1029/RG020i001p00045, 1982.

Cuevas, C. A., Maffezzoli, N., Corella, J. P., Spolaor, A., Vallelonga, P., Kjær, H. A., Simonsen, M., Winstrup, M., Vinther, B., Horvat, C., Fernandez, R. P., Kinnison, D., Lamarque, J. F.,

565 Barbante, C. and Saiz-Lopez, A.: Rapid increase in atmospheric iodine levels in the North Atlantic since the mid-20th century, Nat. Commun., 9, 1452, doi:10.1038/s41467-018-03756-1, 2018.

Curran, M. A. J., van Ommen, T. D., Morgan, V. I., Phillips, K. L. and Palmer, A. S.: Ice core evidence for Antarctic sea ice decline since the 1950s, Science (80-. )., 302(5648), 1203-1206, doi:10.1126/science.1087888, 2003.

570 Dansgaard, W., Johnsen, S. J., Møller, J. and Langway, C. C.: One Thousand Centuries of Climatic Record from Camp Century on the Greenland Ice Sheet, Science (80-. )., 166(3903), 377-380 [online] Available from: http://science.sciencemag.org/content/166/3903/377.abstract, 1969.

Eichler, A., Schwikowski, M. and Gäggeler, H. W.: Meltwater-induced relocation of chemical species in Alpine firn Meltwater-induced relocation of chemical species in Alpine firn, Tellus Ser.

575 B-Chemical Phys. Meteorol., 53B, 192-203, doi:10.3402/tellusb.v53i2.16575, 2001.

EPICA Community members: Eight glacial cycles from an Antarctic ice core, Nature, 429, 623628, doi:10.1038/nature02599, 2004.

Førland, E. J., Benestad, R., Hanssen-Bauer, I., Haugen, J. E. and Skaugen, T. E.: Temperature and Precipitation Development at Svalbard 1900-2100, Adv. Meteorol., 2011(893790), 1-14, doi:10.1155/2011/893790, 2011. 
Frieß, U., Deutschmann, T., Gilfedder, B. S., Weller, R. and Platt, U.: Iodine monoxide in the Antarctic snowpack, Atmos. Chem. Phys., 10(5), 2439-2456, doi:10.5194/acp-10-2439-2010, 2010.

Goto-Azuma, K., Nakawo, M., Jinkang, H., Watanabe, O. and Azuma, N.: Melt-induced relocation of ions in glaciers and in a seasonal snowpack, Snow Ice Cover. Interact. with Atmos. Ecosyst. (Proceedings Yokohama Symp. J2 J5, July 1993), 223, 287-297, 1994.

Isaksson, E., Kekonen, T., Moore, J. and Mulvaney, R.: The methanesulfonic acid (MSA) record in a Svalbard ice core, Ann. Glaciol. Vol 42, 2005, 42, 345-351, doi:10.3189/172756405781812637, 2005.

Johannessen, M., Dale, T., Gjessing, E. T., Henriksen, A. and Wright, R. F.: Acid precipitation in

590 Norway: the regional distribution of contaminants in snow ant the chemical concentration processes during snowmelt, IAHS Publ., 118: 116-1, 1977.

Kawamura, K., Narukawa, M., Li, S.-M. and Barrie, L. A.: Size distributions of dicarboxylic acids and inorganic ions in atmospheric aerosols collected during polar sunrise in the Canadian high Arctic, J. Geophys. Res., 112(D10), doi:10.1029/2006jd008244, 2007.

595 Kohler, J., James, T. D., Murray, T., Nuth, C., Brandt, O., Barrand, N. E., Aas, H. F. and Luckman, A.: Acceleration in thinning rate on western Svalbard glaciers, Geophys. Res. Lett., 34(18), 1-5, doi:10.1029/2007GL030681, 2007.

Kuhn, M.: The nutrient cycle through snow and ice , a review, Aquat. Sci., 63(3), 150-167, doi:10.1007/PL00001348, 2001.

600 Legrand, M. and Mayewski, P.: Glaciochemistry of polar ice cores: A review, Rev. Geophys., 35(3), 219-243, doi:10.1029/96RG03527, 1997.

Maffezzoli, N., Spolaor, A., Barbante, C., Bertò, M., Frezzotti, M. and Vallelonga, P.: Bromine, iodine and sodium in surface snow along the 2013 Talos Dome - GV7 traverse (northern Victoria Land, East Antarctica), Cryosph., 11, 693-705, doi:10.5194/tc-11-693-2017, 2017.

605 Maturilli, M., Herber, A. and König-Langlo, G.: Climatology and time series of surface meteorology in Ny-Ålesund, Svalbard, Earth Syst. Sci. Data, 5(1), 155-163, doi:10.5194/essd-5155-2013, 2013.

Minikin, A., Legrand, M., Hall, J., Wagenbach, D., Kleefeld, C., Wolff, E., Pasteur, E. C. and Ducroz, F.: Sulfur-containing species (sulfate and methanesulfonate) in coastal Antarctic aerosol 610 and precipitation, J. Geophys. Res., 103(D9), 10975-10990, doi:10.1029/98jd00249, 1998.

Moore, G. W. K.: The December 2015 North Pole Warming Event and the Increasing Occurrence of Such Events, Sci. Rep., 6(39084), doi:10.1038/srep39084, 2016.

Nilsson, J., Vallelonga, P., Simonsen, S. B., Sørensen, L. S., Forsberg, R., Dahl-jensen, D., Hirabayashi, M. and Goto-azuma, K.: Greenland 2012 melt event effects on CryoSat-2 radar 615 altimetry, Geophys. Res. Lett., 42, 3919-3926, doi:10.1002/2015GL063296.1., 2015.

Pohjola, V. A., Moore, J. C., Isaksson, E., Jauhiainen, T., van de Wal, R. S. W., Martma, T., Meijer, H. A. J. and Vaikmae, R.: Effect of periodic melting on geochemical and isotopic signals in an ice core from Lomonosovfonna, Svalbard, J. Geophys. Res., 107(D4), doi:10.1029/2000jd000149, 2002.

620 Rinke, A., Maturilli, M., Graham, R. M., Matthes, H., Handorf, D., Cohen, L., Hudson, S. R. and Moore, J. C.: Extreme cyclone events in the Arctic: Wintertime variability and trends, Environ. Res. Lett., 12(094006), doi:10.1088/1748-9326/aa7def, 2017.

Röthlisberger, R., Mulvaney, R., Wolff, E. W., Hutterli, M. A., Bigler, M., Sommer, S. and Jouzel, J.: Dust and sea salt variability in central East Antarctica (Dome C) over the last 45 kyrs and its 625 implications for southern high-latitude climate, Geophys. Res. Lett., 29(20), 24-1-24-4, doi:10.1029/2002GL015186, 2002.

Schüpbach, S., Fischer, H., Bigler, M., Erhardt, T., Gfeller, G., Leuenberger, D., Mini, O., 
Mulvaney, R., Abram, N. J., Fleet, L., Frey, M. M., Thomas, E., Svensson, A., Dahl-Jensen, D., Kettner, E., Kjaer, H., Seierstad, I., Steffensen, J. P., Rasmussen, S. O., Vallelonga, P., Winstrup,

630 M., Wegner, A., Twarloh, B., Wolff, K., Schmidt, K., Goto-Azuma, K., Kuramoto, T., Hirabayashi, M., Uetake, J., Zheng, J., Bourgeois, J., Fisher, D., Zhiheng, D., Xiao, C., Legrand, M., Spolaor, A., Gabrieli, J., Barbante, C., Kang, J. H., Hur, S. D., Hong, S. B., Hwang, H. J., Hong, S., Hansson, M., Iizuka, Y., Oyabu, I., Muscheler, R., Adolphi, F., Maselli, O., McConnell, J. and Wolff, E. W.: Greenland records of aerosol source and atmospheric lifetime changes from the Eemian to the 635 Holocene, Nat. Commun., 9, 1476, doi:10.1038/s41467-018-03924-3, 2018.

Sigl, M., McConnell, J. R., Toohey, M., Curran, M., Das, S. B., Edwards, R., Isaksson, E., Kawamura, K., Kipfstuhl, S., Krüger, K., Layman, L., Maselli, O. J., Motizuki, Y., Motoyama, H., Pasteris, D. R. and Severi, M.: Insights from antarctica on volcanic forcing during the common era, Nat. Clim. Chang., 4(8), 693-697, doi:10.1038/nclimate2293, 2014.

640 Spolaor, A., Vallelonga, P., Gabrieli, J., Martma, T., Bjorkman, M. P., Isaksson, E., Cozzi, G., Turetta, C., Kjaer, H. A., Curran, M. A. J., Moy, A. D., Schoenhardt, A., Blechschmidt, A. M., Burrows, J. P., Plane, J. M. C. and Barbante, C.: Seasonality of halogen deposition in polar snow and ice, Atmos. Chem. Phys., 14(18), 9613-9622, doi:10.5194/acp-14-9613-2014, 2014.

Spolaor, A., Vallelonga, P., Turetta, C., Maffezzoli, N., Cozzi, G., Gabrieli, J., Barbante, C., Goto-

645 Azuma, K., Saiz-Lopez, A., Cuevas, C. A. and Dahl-Jensen, D.: Canadian arctic sea ice reconstructed from bromine in the Greenland NEEM ice core, Sci. Rep., 6(August), 1-8, doi:10.1038/srep33925, 2016a.

Spolaor, A., Barbaro, E., Christille, J. M., Kirchgeorg, T., Giardi, F., Cappelletti, D., Turetta, C., Bernagozzi, A., Björkman, M. P., Bertolini, E. and Barbante, C.: Evolution of the Svalbard annual 650 snow layer during the melting phase, Rend. Lincei, 27, doi:10.1007/s12210-015-0500-8, $2016 \mathrm{~b}$.

Stenni, B., Buiron, D., Frezzotti, M., Albani, S., Barbante, C., Bard, E., Barnola, J. M., Baroni, M., Baumgartner, M., Bonazza, M., Capron, E., Castellano, E., Chappellaz, J., Delmonte, B., Falourd, S., Genoni, L., Iacumin, P., Jouzel, J., Kipfstuhl, S., Landais, A., Lemieux-Dudon, B., Maggi, V., Masson-Delmotte, V., Mazzola, C., Minster, B., Montagnat, M., Mulvaney, R., Narcisi, B., Oerter,

655 H., Parrenin, F., Petit, J. R., Ritz, C., Scarchilli, C., Schilt, A., Schüpbach, S., Schwander, J., Selmo, E., Severi, M., Stocker, T. F. and Udisti, R.: Expression of the bipolar see-saw in Antarctic climate records during the last deglaciation, Nat. Geosci., 4, 46-49 [online] Available from: https://doi.org/10.1038/ngeo1026, 2011.

Valt, M. and Salvatori, R.: Snowpack characteristics of Brøggerhalvøya, Svalbard Islands, Rend. 660 Lincei, 27(1), 129-136, doi:10.1007/s12210-016-0509-7, 2016.

Vega, C. P., Pohjola, V. A., Beaudon, E., Claremar, B., Van Pelt, W. J. J., Pettersson, R., Isaksson, E., Martma, T., Schwikowski, M. and Bøggild, C. E.: A synthetic ice core approach to estimate ion relocation in an ice field site experiencing periodical melt: A case study on Lomonosovfonna, Svalbard, Cryosph., 10(3), 961-976, doi:10.5194/tc-10-961-2016, 2016.

665 Wolff, E. W., Barbante, C., Becagli, S., Bigler, M., Boutron, C. F., Castellano, E., de Angelis, M., Federer, U., Fischer, H., Fundel, F., Hansson, M., Hutterli, M., Jonsell, U., Karlin, T., Kaufmann, P., Lambert, F., Littot, G. C., Mulvaney, R., Röthlisberger, R., Ruth, U., Severi, M., SiggaardAndersen, M. L., Sime, L. C., Steffensen, J. P., Stocker, T. F., Traversi, R., Twarloh, B., Udisti, R., Wagenbach, D. and Wegner, A.: Changes in environment over the last 800,000 years from chemical 670 analysis of the EPICA Dome C ice core, Quat. Sci. Rev., 29(1-2), 285-295, doi:10.1016/j.quascirev.2009.06.013, 2010. 


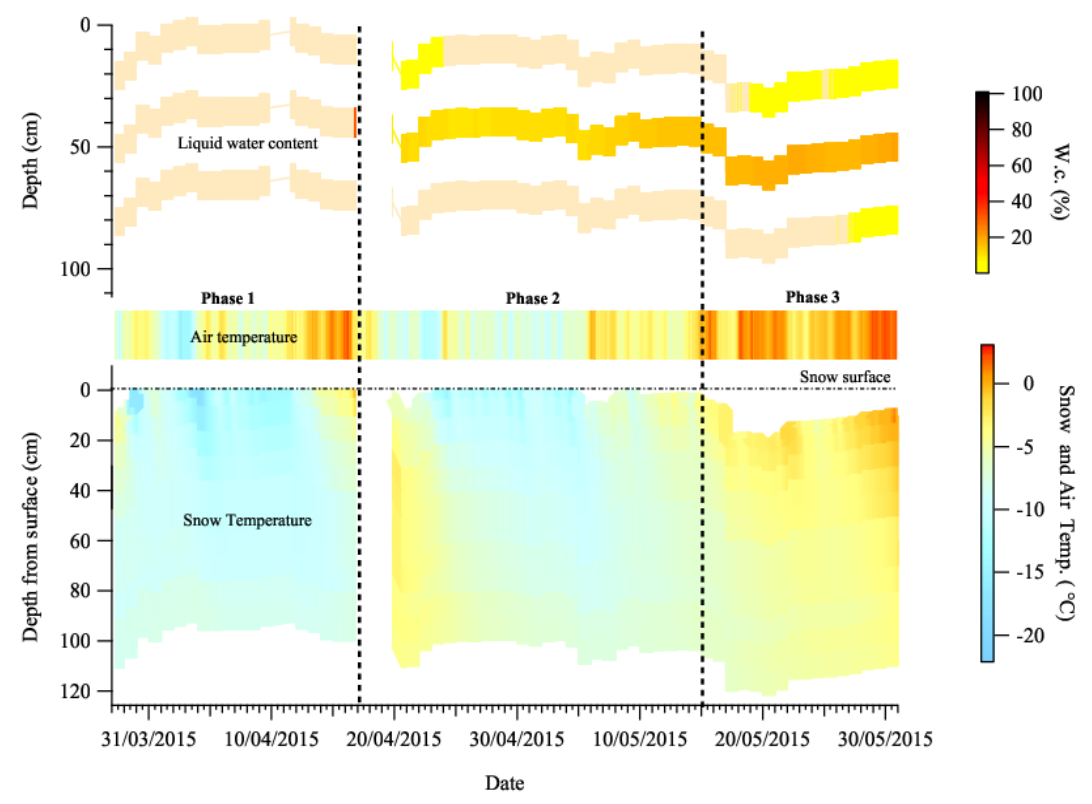

675 Fig. 1 a) liquid water content (LWC) measured in three different layers at $25 \mathrm{~cm}, 50 \mathrm{~cm}$ and $75 \mathrm{~cm}$ : red indicates the highest $L W C$ value and light blue the lowest $(0 \%$ or absence of LWC); b air temperature measured $2 \mathrm{~m}$ above the ground at the AWIIIPEV station located in $\mathrm{Ny}$-Ålesund and c) snow temperature of the first meter of snow (corrected in function of the accumulation). Red indicates the warmest $\left(\sim+3{ }^{\circ} \mathrm{C}\right)$ and dark blue the coldest $\left(\sim-22{ }^{\circ} \mathrm{C}\right)$. 
https://doi.org/10.5194/tc-2019-124

Preprint. Discussion started: 5 June 2019

(c) Author(s) 2019. CC BY 4.0 License.

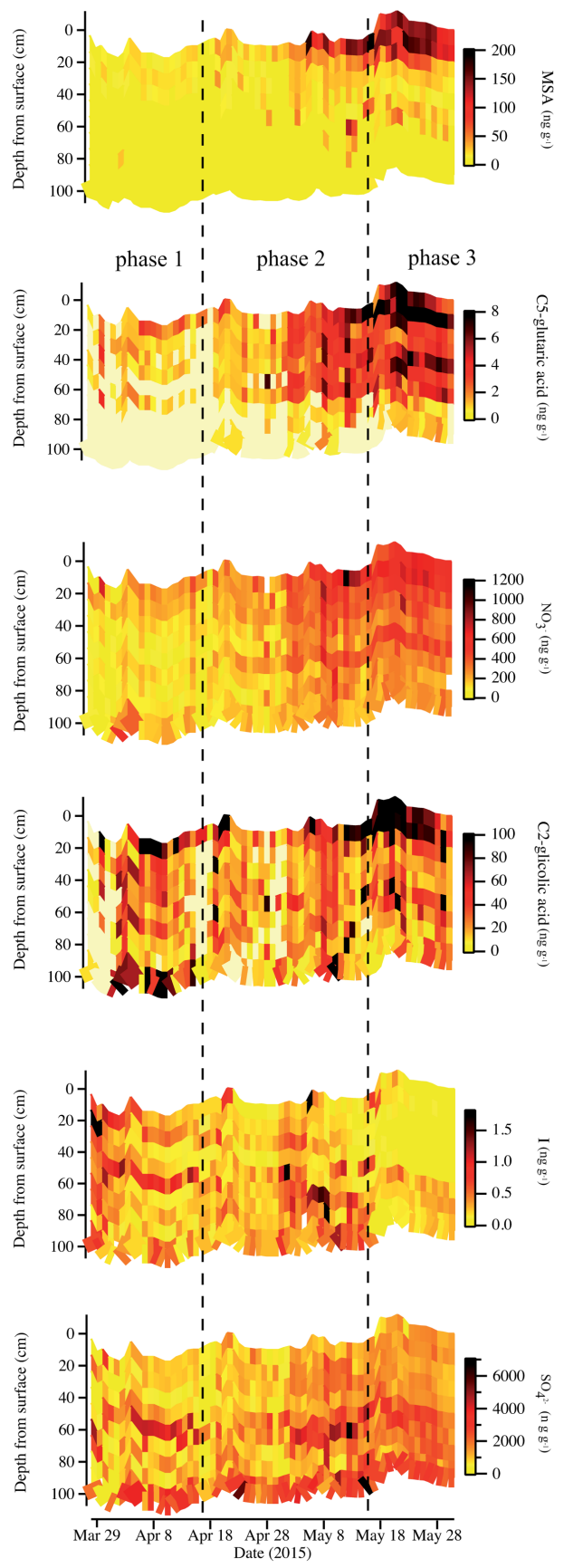

Figure 2. The concentrations of each biogenic ion (MSA, NO3-, $\mathrm{C}_{2}$-glycolic and $\mathrm{C}_{5}$-glutari acids) and total iodide and sulfate ( $\mathrm{ng} \mathrm{g}^{-1}$ ) were measured in the daily $1 \mathrm{~m}$ snow pit with a 10 cm resolution: dark red represents the highest concentration, light colors the lowest concentration. Each value is corrected for the daily accumulation/ablation. 
https://doi.org/10.5194/tc-2019-124

Preprint. Discussion started: 5 June 2019

(c) Author(s) 2019. CC BY 4.0 License.
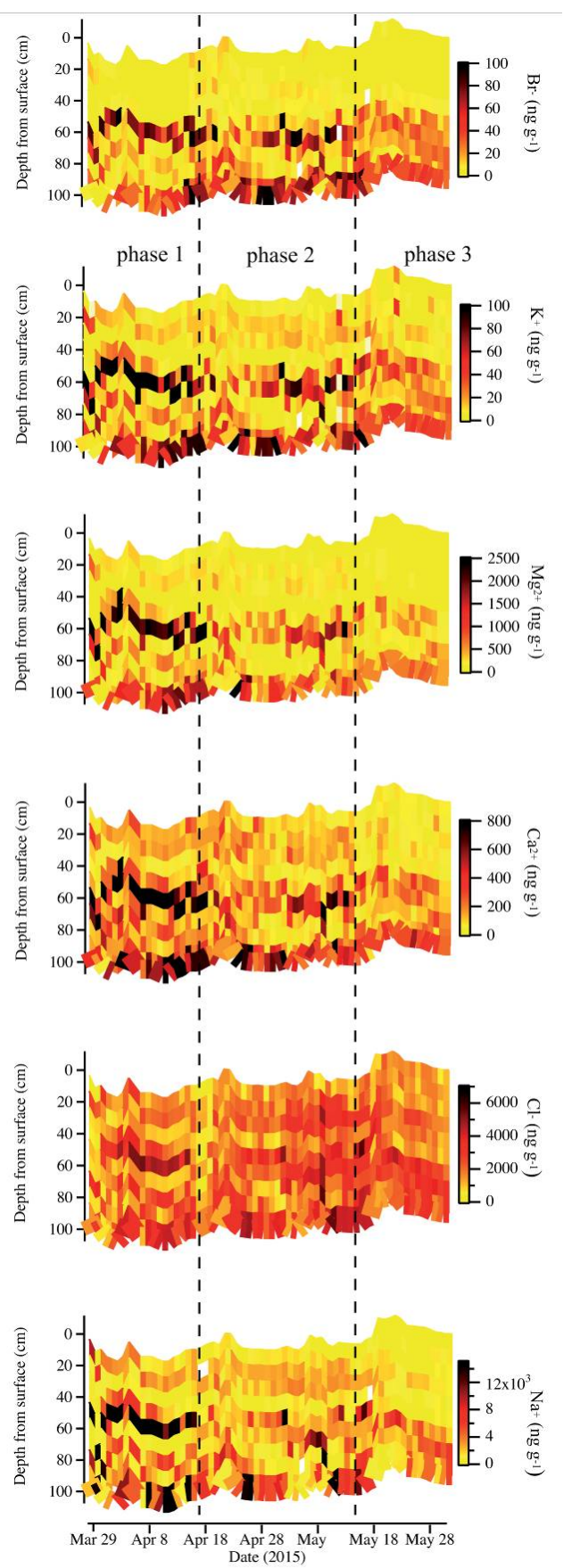

Figure 3. The concentrations of $\mathrm{Br}^{-}, \mathrm{K}^{+}, \mathrm{Mg}^{2+}, \mathrm{Ca}^{2+}, \mathrm{Cl}^{-}$, and $\mathrm{Na}^{+}\left(\mathrm{ng} \mathrm{g}^{-1}\right)$ were measured in the daily $1 \mathrm{~m}$ snow pit with a $10 \mathrm{~cm}$ resolution: dark red represents the highest concentration, light colors the lowest concentration. Each value is corrected for the daily accumulation/ablation. 
https://doi.org/10.5194/tc-2019-124

Preprint. Discussion started: 5 June 2019

(c) Author(s) 2019. CC BY 4.0 License.

690 Table 1. Summary of the statistical analysis of the biogenic ions series to identify the presence of a positive (+) or negative (-) level shift for each layer after the rain and melting events. P-values below the conventional value of 0.05 are marked in bold. Degree of significance: highly significant $\mathrm{p}<0.001^{* * *}$, significant $0.001 \leq \mathrm{p}<0.01 * *$, weakly significant $0.01 \leq \mathrm{p}<0.05$.

\begin{tabular}{|c|c|c|c|c|c|c|}
\hline \multirow[t]{2}{*}{ layer } & \multicolumn{3}{|c|}{ rain event } & \multicolumn{3}{|c|}{ melting event } \\
\hline & ion & Level shift & $p$-value & ion & Level shift & p-value \\
\hline & $\mathrm{NO} 3$ & - & $0.019 *$ & MSA & + & $<0.001 * * *$ \\
\hline \multirow[t]{5}{*}{$10-20 \mathrm{~cm}$} & MSA & - & 0.117 & $\mathrm{C} 5$ & + & $0.004 * *$ \\
\hline & $\mathrm{C} 5$ & - & 0.33 & $\mathrm{C} 2$ & + & 0.013* \\
\hline & $\mathrm{C} 2$ & - & 0.805 & NO3 & - & 0.102 \\
\hline & ion & Level shift & p-value & ion & Level shift & p-value \\
\hline & NO3 & - & $<0.001 * * *$ & MSA & - & $0.002 * *$ \\
\hline \multirow[t]{5}{*}{$30-50 \mathrm{~cm}$} & $\mathrm{C} 5$ & - & $<0.001 * * *$ & NO3 & - & 0.531 \\
\hline & MSA & - & $0.017 *$ & $\mathrm{C} 2$ & - & 0.588 \\
\hline & $\mathrm{C} 2$ & - & 0.202 & $\mathrm{C} 5$ & - & 0.616 \\
\hline & ion & Level shift & p-value & ion & Level shift & p-value \\
\hline & $\mathrm{C} 5$ & + & $0.004 * *$ & $\mathrm{C} 5$ & + & $0.002 * *$ \\
\hline \multirow[t]{3}{*}{$60-100 \mathrm{~cm}$} & $\mathrm{C} 2$ & - & $0.007 * *$ & $\mathrm{C} 2$ & - & 0.299 \\
\hline & MSA & - & 0.107 & MSA & + & 0.334 \\
\hline & NO3 & - & 0.604 & NO3 & + & 0.942 \\
\hline
\end{tabular}


https://doi.org/10.5194/tc-2019-124

Preprint. Discussion started: 5 June 2019

(c) Author(s) 2019. CC BY 4.0 License.

Table 2. Summary of the statistical analysis of the non-biogenic ions series to identify the presence of a positive (+) or negative (-) level shift for each layer after the rain and melting events. P-values below the conventional value of 0.05 are marked in bold. Degree of significance: highly significant $\mathrm{p}<0.001 * * *$, significant $0.001 \leq \mathrm{p}<0.01 * *$, weakly significant $0.01 \leq \mathrm{p}<0.05$.

\begin{tabular}{|c|c|c|c|c|c|c|}
\hline \multirow[t]{2}{*}{ layer } & \multicolumn{3}{|c|}{ rain event } & \multicolumn{3}{|c|}{ melting event } \\
\hline & ion & Level shift & p-value & ion & Level shift & p-value \\
\hline \multirow{8}{*}{$10-40 \mathrm{~cm}$} & $\mathrm{Br}$ & + & $<0.001 * * *$ & $\mathrm{Na}$ & - & $<0.001 * * *$ \\
\hline & $\mathrm{SO} 4$ & + & $<0.001 * * *$ & $\mathrm{Br}$ & + & $0.002 * *$ \\
\hline & K & + & 0.080 & CI & - & $0.012 *$ \\
\hline & $\mathrm{Ca}$ & + & 0.316 & $\mathrm{Mg}$ & - & $0.030 *$ \\
\hline & $\mathrm{Cl}$ & + & 0.399 & $\mathrm{Ca}$ & - & $0.048 *$ \\
\hline & $\mathrm{Na}$ & + & 0.473 & $\mathrm{SO} 4$ & - & 0.095 \\
\hline & $\mathrm{Mg}$ & - & 0.855 & $\mathrm{~K}$ & - & 0.758 \\
\hline & I & + & 0.961 & I & + & 0.932 \\
\hline \multirow{9}{*}{$50 \mathrm{~cm}$} & ion & Level shift & $p$-value & ion & Level shift & $p$-value \\
\hline & $\mathrm{Br}$ & + & $<0.001 * * *$ & $\mathrm{Ca}$ & - & $<0.001 * * *$ \\
\hline & $\mathrm{Ca}$ & - & $<0.001 * * *$ & I & - & $0.002 * *$ \\
\hline & $\mathrm{Mg}$ & - & $<0.001 * * *$ & $\mathrm{Mg}$ & - & $0.011^{*}$ \\
\hline & $\mathrm{K}$ & - & $<0.001 * * *$ & $\mathrm{CI}$ & - & $0.026 *$ \\
\hline & $\mathrm{SO} 4$ & - & $<0.001 * * *$ & $\mathrm{Br}$ & + & 0.057 \\
\hline & I & - & $<0.001 * * *$ & $\mathrm{Na}$ & - & 0.172 \\
\hline & $\mathrm{Na}$ & - & $<0.001 * * *$ & $\mathrm{SO} 4$ & - & 0.250 \\
\hline & $\mathrm{Cl}$ & - & $0.037 *$ & $\mathrm{~K}$ & - & 0.393 \\
\hline \multirow{9}{*}{$60-90 \mathrm{~cm}$} & ion & Level shift & p-value & ion & Level shift & p-value \\
\hline & $\mathrm{Br}$ & + & $<0.001 * * *$ & $\mathrm{Br}$ & - & $<0.001 * * *$ \\
\hline & $\mathrm{Na}$ & - & $0.006 * *$ & $\mathrm{Mg}$ & - & $<0.001 * * *$ \\
\hline & $\mathrm{Mg}$ & - & $0.012 *$ & $\mathrm{~K}$ & - & $<0.001 * * *$ \\
\hline & $\mathrm{K}$ & - & $0.014^{*}$ & $\mathrm{SO} 4$ & - & $<0.001 * * *$ \\
\hline & $\mathrm{Ca}$ & - & 0.051 & I & - & $<0.001 * * *$ \\
\hline & $\mathrm{SO} 4$ & - & 0.131 & $\mathrm{Na}$ & - & $<0.001 * * *$ \\
\hline & $\mathrm{Cl}$ & - & 0.341 & $\mathrm{Ca}$ & - & $0.007 * *$ \\
\hline & I & + & 0.797 & $\mathrm{Cl}$ & - & $0.010^{*}$ \\
\hline \multirow{6}{*}{$100 \mathrm{~cm}$} & ion & Level shift & $p$-value & ion & Level shift & $p$-value \\
\hline & $\mathrm{Br}$ & + & $<0.001 * * *$ & I & - & $<0.001 * * *$ \\
\hline & $\mathrm{Mg}$ & - & 0.079 & $\mathrm{Ca}$ & - & 0.477 \\
\hline & $\mathrm{Ca}$ & - & 0.097 & $\mathrm{Br}$ & - & 0.709 \\
\hline & $\mathrm{Na}$ & - & 0.116 & $\mathrm{Na}$ & - & 0.761 \\
\hline & $\mathrm{K}$ & - & 0.133 & $\mathrm{SO} 4$ & + & 0.833 \\
\hline
\end{tabular}


https://doi.org/10.5194/tc-2019-124

Preprint. Discussion started: 5 June 2019

(C) Author(s) 2019. CC BY 4.0 License.

735 
Table 3. Summary of elution sequence obtained in this study for each stratum during rain event and melting phase. A comparison with previous investigations about the preferential elution sequence of melting phase is also reported. In this study the elution sequences are expressed in terms of statistical significance of the level shift following the conventional classification: highly significant $\mathrm{p}<0.001^{* * *}$, significant $0.001 \leq \mathrm{p}<0.01^{* *}$, weakly significant $0.01 \leq \mathrm{p}<0.05$.

\begin{tabular}{|c|c|c|c|}
\hline depth & Rain event & Melting phase & \\
\hline $10-40 \mathrm{~cm}$ & $\mathrm{Br}^{-* * *}, \mathrm{SO}_{4}^{2-* * *}$ & $\mathrm{Na}^{+* * *}>\mathrm{Br}^{-* *}>\mathrm{Cl}^{-*}, \mathrm{Mg}^{2+*}, \mathrm{Ca}^{*}$ & \\
\hline $50 \mathrm{~cm}$ & $\begin{array}{l}\mathrm{Br}^{-* * *}, \quad \mathrm{~K}^{+* * *}, \quad \mathrm{Mg}^{2+* * *}, \mathrm{Ca}^{2+* * *}, \\
\mathrm{Na}^{+* * *}, \mathrm{SO}_{4}^{2-* * *}, \mathrm{I}^{-* * *}>\mathrm{Cl}^{-*}\end{array}$ & $\mathrm{Ca}^{2+* * *}>\mathrm{I}^{-* *}>\mathrm{Mg}^{2+*}, \mathrm{Cl}^{-*}$ & this study \\
\hline $60-90 \mathrm{~cm}$ & $\mathrm{Br}^{-* * *}>\mathrm{Na}^{+* *}>\mathrm{Mg}^{2+*}, \mathrm{~K}^{+*}$ & $\begin{array}{l}\mathrm{Br}^{-* * *}, \mathrm{~K}^{+* * *}, \mathrm{Mg}^{2+* * *}, \mathrm{Na}^{+* * *}, \mathrm{SO}_{4}{ }^{2-} \\
* * *, \mathrm{I}^{-* * *}>\mathrm{Ca}^{2+* *}>\mathrm{Cl}^{-*}\end{array}$ & \\
\hline $100 \mathrm{~cm}$ & $\mathrm{Br}^{-* * *}$ & $\mathrm{I}^{-* * *}$ & \\
\hline $10-20 \mathrm{~cm}$ & $\mathrm{NO}_{3}^{-*}$ & $\mathrm{MSA}^{* * *}>\mathrm{C} 5 * *>\mathrm{C} 2 *$ & \\
\hline $30-50 \mathrm{~cm}$ & $\mathrm{NO}_{3}^{-* * *}, \mathrm{C} 2 * * *>\mathrm{MSA}^{*}$ & MSA** & this study \\
\hline $60-100 \mathrm{~cm}$ & $\mathrm{C} 5^{* *}, \mathrm{C} 2 * *$ & $\mathrm{C} 5 * *$ & \\
\hline $\begin{array}{l}\text { Snow pit and firn } \\
\text { core at ABB dug in } \\
\text { the mid melt season }\end{array}$ & & $\mathrm{NO}_{3}->\mathrm{Mg}^{2+}>\mathrm{SO}_{4}{ }^{2}, \mathrm{Na}^{+}>\mathrm{Ca}^{2+}, \mathrm{Cl}->\mathrm{K}^{+}$ & $\begin{array}{l}\text { (Goto- } \\
\text { Azuma et } \\
\text { al., 1994) }\end{array}$ \\
\hline $\begin{array}{l}\text { Review of field and } \\
\text { laboratory } \\
\text { measurements of } \\
\text { entire snowpack }\end{array}$ & & $\begin{array}{l}\text { alkali metals, alkaline earth metals, } \\
\left.\text { cations (other than } \mathrm{NH}_{4}^{+}\right)>\mathrm{SO}_{4}^{2-}>\mathrm{NO}_{3}^{-} \\
>\mathrm{Cl}^{-}>\mathrm{NH}_{4}^{+}>\mathrm{H}_{2} \mathrm{O}_{2}\end{array}$ & $\begin{array}{l}\text { (Kuhn, } \\
\text { 2001) }\end{array}$ \\
\hline $\begin{array}{l}\text { Snowpit } \\
\text { Midtre Lovenbreen, } \\
\text { glacier close to ABB }\end{array}$ & & $\mathrm{Cl}^{-}, \mathrm{SO}_{4}^{2-}>\mathrm{NO}_{3}^{-}, \mathrm{Na}^{+}, \mathrm{K}^{+}>\mathrm{Mg}^{2+}>\mathrm{Ca}^{2+}$ & $\begin{array}{l}\text { (Björkman } \\
\text { et al., } \\
2014)\end{array}$ \\
\hline $\begin{array}{l}\text { Ice core } \\
\text { Lomonosovfonna } \\
\text { glacier, Svalbard }\end{array}$ & & $\mathrm{NO}_{3}->\mathrm{SO}_{4}{ }^{2-}, \mathrm{Mg}^{2+}, \mathrm{Cl}^{-}, \mathrm{K}^{+}, \mathrm{Na}^{+}$ & $\begin{array}{l}\text { (Vega et } \\
\text { al., 2016) }\end{array}$ \\
\hline
\end{tabular}

